\title{
Electrical failure during cardiopulmonary bypass: a critical moment
}

\author{
Ahmet Baris Durukan ${ }^{1}$, Hasan Alper Gurbuz ${ }^{1}$, Gokhan Ozcelik ${ }^{2}$, Cem Yorgancioglu ${ }^{1}$ \\ ${ }^{1}$ Department of Cardiovascular Surgery, Memorial Ankara Hospital, Ankara, Turkey \\ 2Perfusion Unit, Memorial Ankara Hospital, Ankara, Turkey
}

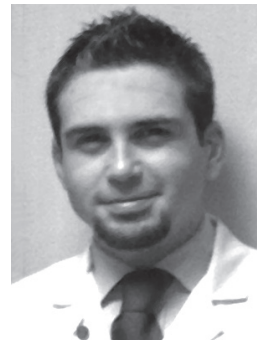

Kardiochirurgia i Torakochirurgia Polska 2016; 13 (2): 143-144

\begin{abstract}
Electrical failure during cardiopulmonary bypass is a crisis situation for the cardiac surgical team. Fortunately, it has a low incidence with low morbidity and mortality rates. Notwithstanding, institutional preventative and management measures should be taken. Here, we report a case of electrical failure during cardiopulmonary bypass, which was successfully managed during the surgery, allowing the patient to recover uneventfully. These unwanted complications can only be managed by promoting awareness and putting in place strategies against them.
\end{abstract}

Key words: cardiopulmonary bypass, electricity, equipment failure analysis.

\section{Introduction}

Electrical failure during cardiopulmonary bypass (CPB) is an undesired situation with possible catastrophic consequences in the operating room. Its incidence is estimated to be 1 per 1000 cases, fortunately with low morbidity and mortality [1]. During 2000 routine CPB cases in our institution within the period of 4 years, 1 case of electrical failure was observed. Different mechanisms of electrical failure have been reported, including mains failure, generator failure, and uninterrupted power supply (UPS) failure [1, 2]. Since these kinds of equipment failure and accidents are very rare, little attention is given to preventative measures concerning electrical supply and backup batteries. Operators should be informed during their education about this life-threatening scenario, since taking the wrong action during a crisis may lead to serious consequences. Panic may cause irrational decisions.

Here, we report a case involving electrical failure during CPB due to a UPS failure, which was managed successfully by the cardiac surgical team.

\section{Streszczenie}

Awaria elektryczności w czasie krążenia pozaustrojowego z użyciem płucoserca jest sytuacją kryzysową dla zespołu kardiochirurgicznego. Na szczęście problem ten występuje rzadko, a związane z nim wskaźniki śmiertelności i chorobowości są niskie. Niemniej jednak w instytucjach medycznych należy przyjąć strategię zapobiegania takim sytuacjom i postępowania z nimi. Artykuł przedstawia przypadek awarii elektrycznej w czasie krążenia pozaustrojowego z użyciem płucoserca, z którą udało się uporać w trakcie zabiegu, co pozwoliło pacjentowi na niepowikłany powrót do zdrowia. Jedynym sposobem radzenia sobie $z$ opisywanymi komplikacjami jest promowanie świadomości problemu i wdrażanie przyjętych wcześniej strategii działania.

Słowa kluczowe: krążenie pozaustrojowe, elektryczność, analiza awarii sprzętu.

\section{Case report}

A 51-year-old, 84-kg male patient with low ejection fraction was undergoing CPB during one-vessel coronary bypass surgery concomitant with the repair of a huge left ventricular aneurysm. Suddenly, the heart-lung machine and the heat exchanger stopped. The other pieces of equipment, including the anesthetic machine, lights, and monitors, remained functional. The console of the pump showed no power supply. Only the power to the protected sockets was interrupted. These sockets were connected to the UPS. Soon, it became apparent that a new neurosurgical navigation device had been used for the first time, which led to the UPS failure. Luckily, when the heart-lung machine and the heat exchanger were shut down, the patient's core temperature was $34^{\circ} \mathrm{C}$, the operative procedures were completed, and the aortic cross clamp had already been released. However, the temperature and hemodynamic parameters were not satisfactory enough to wean the patient from CPB. In the first place, the venous line was clamped, and hand-cranking was initiated simul-

Address for correspondence: Assoc. Prof. Ahmet Baris Durukan, Memorial Ankara Hospital, Department of Cardiovascular Surgery, Umit Mahallesi 2463. sokak Sedef Sitesi 4/18, Cankaya, 06810 Ankara, Turkey, phone: +90 5322273814, fax: +90 3123546620,

e-mail: barisdurukan@yahoo.com 
taneously with adjustment of venous clamping in order to maintain the reservoir level. The sockets were replaced with standard sockets, but the machines did not function. Therefore, hand-cranking was performed for 10 minutes. Surface heating was conducted, inotropic support was initiated to increase blood pressure, and, finally, the patient could be weaned with a core body temperature of $35^{\circ} \mathrm{C}$. The patient recovered uneventfully.

\section{Discussion}

Electrical failure during CPB leads to the shutdown of the heart-lung machine, which may not be restored immediately depending on the mechanisms of the failure and the technical status of the hospital. This possibly devastating scenario may only be managed with the help of a ready surgical, perfusionist, and technical team. Despite the low rates of mortality and morbidity, in a large survey reporting 200 interrupted cases, hospital stay was extended in seven patients [3]. In such a case, electrical personnel should be immediately informed about the electrical failure. Portable lights with backup batteries should be brought if required. Then, certain considerations and requirements should be met. Systemic perfusion needs to be restored. The key point is that, even when the pump stops, the venous return to the reservoir continues, so the first step should consist in clamping the venous line. The venous return should be controlled, and the reservoir level should be maintained [1, 4]. This duty may be performed by some other members of the team to allow the perfusionist to deal with the restoration of systemic perfusion. If the heart is contracting when the pump stops, only the occlusion of the venous line may restore systemic perfusion, sometimes with the help of inotropic support. If the aorta is clamped, the only solution is hand-cranking [1, 2, 4, 5]. Hand-cranking is effective in terms of restoring systemic perfusion, but the universally accepted time limit for a single person is 15 minutes, to prevent exhaustion [1, 4]. Even when hand-cranking was performed for only 1 minute, the flow rate achieved in the second half of that minute was not as high as desired. In the same study, Tomizawa et al. documented that the target flow rate could be achieved without practice, but adjustment of the venous reservoir level by clamping required practice [4]. Correct rotation is also essential. During handcranking, other solutions should also be sought to restore the electrical supply. It is recommended that the surgeon should intermittently palpate the aorta in order to evaluate the efficacy of hand-cranking [1]. If it is not possible to restore the electrical supply immediately, the aortic cross clamp should be released as soon as possible even at the expense of incomplete surgery [5]. If the heat exchanger is also affected, warming should be ensured by other means. At the same time, battery and other sources of power supply to monitors, anesthetic machines, surgical lamps, and defibrillators should be provided. Our team followed a similar strategy. We clamped the venous line first, performed hand-cranking, and weaned the patient from cardiopulmonary bypass as soon as possible.

Preventative measures are as important as management measures. The electrical supply of the institution should be dual, so that if one element shuts down, the other will continue to function. The UPS should be situated in an adequate environment to prevent overheating, and the battery condition should be checked periodically. Backup batteries for pump consoles should be supplied if not present, and should be checked frequently. A separate, portable, petrol-driven generator with extension cables may be kept close to the operation room [1,4]. Professional electrical personnel should be available on call.

\section{Conclusions}

Electrical failure during CPB may result in devastating injury to the patient and the surgical team if no preventative measures are taken and no management strategies are developed. Taking action without panic and adhering to a previously designed algorithm is essential for all surgical teams. Venous clamping is the key feature, followed by hand-cranking if required.

\section{Acknowledgments}

The described patient was operated on in the former institute of the authors, Medicana International Ankara Hospital.

\section{Disclosure}

Authors report no conflict of interest.

\section{References}

1. Hargrove M, Ramish BC, O’Donnell A, Aherne T. Electrical failure during cardiopulmonary bypass: an evaluation of incidence, causes, management and guidelines for preventive measures. Perfusion 2002; 17: 369-372.

2. Nishiyama K, Komori M, Kdaka M, Tomizawa Y. Crisis in the operating room: fires, explosions and electrical accidents. J Artif Organs 2010; 13: 129-133.

3. Stammers AH, Mejak BL. An update of perfusion safety: does the type of perfusion practice affect the rate of incidents related to cardiopulmonary bypass? Perfusion 2001; 16: 189-198.

4. Tomizawa Y, Tokumine A, Ninomija S, Momose N, Matayoshi T. Quantitaive evaluation of hand cranking a roller pump in a crisis management drill. J Artif Organs 2008; 11: 117-122.

5. Troinas CA. Complete electrical failure during cardiopulmonary bypass. Anesthesiology 1995; 82: 298-302. 